\title{
Functional assessment of the sciatic nerve after repair with local delivery of FK 506 in rats
}

\author{
Pramod K Nelluri MD MCh ${ }^{1}$, Robert C Lyons MD ${ }^{1}$, \\ Chet L Nastala $M D^{1,2}$, Jaime R Garza MD DDS ${ }^{1}$
}

PK Nelluri, RC Lyons, CL Nastala, JR Garza. Functional assessment of the sciatic nerve after repair with local delivery of FK 506 in rats. Can J Plast Surg 2002;10(1):21-25.

Difficulties with nerve repair are addressed principally in two ways - one is a meticulous apposition of nerve fibres by microsurgical techniques and the other is the facilitation of the regeneration of proximal axons by neurotrophic factors. The latter concept essentially involves optimizing the microenvironment at the site of injury by biochemical influences. FK 506 (tacrolimus), an immunosuppressive agent, has been recently found to have nerve regenerative potential in experimental animals; however, the various toxic effects of the drug, when used systemically (which has been the case in all of these experiments), limit its clinical use. To prevent such toxic effects of FK 506 in a nerve injury model, a local drug delivery method was developed by suspending a known concentration of FK 506 in fibrin glue (fibrin sealant) to release slowly $1 \mathrm{mg}$ of the drug at the local site.

MATERIALS AND METHODS: The sciatic nerve was tran- sected in 18 rats and primary microsurgical repair was performed. Rats in group 1, the control group, had transection and primary repair, those in group 2 had transection and primary repair reinforced with fibrin sealant, and those in group 3 had primary repair that was reinforced with fibrin sealant and FK 506 (1 mg). A walking track analysis was performed, beginning in the second week, to evaluate functional recovery of the sciatic nerve.

RESULTS: Overall, the animals that received FK 506 showed earlier recovery than those in the control group. Further, mean footprint length factors of the rats in group 3 showed significant early improvement between four and five weeks after surgery, whereas the improvements in groups 1 and 2 started toward normalization a week later, between five and six weeks after surgery. The experimental goal of the study was to determine whether locally delivered FK 506 is beneficial to nerve regeneration.

Key Words: Fibrin Sealant; FK 506; Nerve Regeneration; Toxicity

Résumé à la page suivante

${ }^{1}$ Division of Plastic and Reconstructive Surgery, University of Texas Health Science Center and ${ }^{2}$ Audie L Murphy VA Hospital, San Antonio, Texas 78229, USA

Correspondence: Dr PK Nelluri, Division of Plastic Surgery, Mediciti Hospitals, 6-30, Anupuram, ECIL Post, Hyderabad, Andhra Pradesh 5000 62, India. Telephone+91-40-7135222,fax+91-40-4755839, e-mail nplasty@bharatmail.com 


\section{Évaluation fonctionnelle du nerf sciatique après sa réparation par l'administration locale de FK 506 chez le rat}

RÉSUMÉ : Les difficultés liées à la réparation des nerfs font appel à deux types d'intervention : l'apposition méticuleuse des fibres nerveuses par la microchirurgie et la facilitation de la régénération des axones proximaux par des facteurs neurotrophiques. Cette dernière intervention consiste essentiellement en l'optimisation du micro-environnement au siège de la lésion par des actions biochimiques. On a découvert récemment que le FK 506 (tacrolimus), un immunodépresseur, avait un pouvoir de régénération nerveuse chez les animaux de laboratoire; toutefois, les divers effets toxiques du médicament, lorsqu'il est administré par voie générale (ce qui a été le cas dans toutes les expériences), en limite l'utilisation clinique. Pour éviter les effets toxiques du FK 506 dans un modèle de lésion nerveuse, nous avons conçu une méthode d'administration locale du médicament en ajoutant une concentration connue de FK 506 en suspension dans de la colle de fibrine (agent de scellement de fibrine) de manière à obtenir une libération lente de $1 \mathrm{mg}$ de médicament au siège de la lésion.
MATÉRIAU ET MÉTHODE : Nous avons procédé à une section transversale du nerf sciatique chez 18 rats, puis à sa réparation primaire par la microchirurgie. Les rats ont été divisés en trois groupes : le premier, le groupe témoin, a subi la section et la réparation primaire; le deuxième a subi les mêmes lésion et traitement mais a reçu, en plus, de la colle de fibrine; le troisième a été soumis aux mêmes interventions que le deuxième, sauf que la colle de fibrine était enrichie de FK 506 (1 mg). Nous avons effectué, au début de la deuxième semaine, une analyse des pistes pour évaluer le rétablissement fonctionnel du nerf sciatique.

RÉSULTATS : Dans l'ensemble, les rats qui ont reçu du FK 506 ont montré un rétablissement plus rapide que ceux du groupe témoin. En outre, les facteurs de longueur moyenne des empreintes de patte chez les rats du troisième groupe ont révélé une amélioration significativement précoce de la marche entre la quatrième et la cinquième semaine après l'opération, tandis que les premiers signes de normalisation chez les rats des deux autres groupes sont apparus une semaine plus tard, soit entre la cinquième et la sixième semaine postopératoire. L'essai avait pour but de déterminer si l'administration locale de FK 506 aurait un effet bénéfique sur la régénération des cellules nerveuses.
$\mathrm{N}$ umerous agents that enhance peripheral nerve regeneration have been identified, and there is much ongoing research regarding pharmacological agents, immune system modulators, enhancing factors and entubulation chambers. Clinically applicable developments from these investigations continue to improve the results of nerve injury treatment.

Regardless of the mechanism by which it is delivered, FK 506 enhances morphological and functional recovery in rats with damaged sciatic nerves $(1,2)$. Further, there is substantial proof that axonal regeneration is dose-dependent in rodent models. Maximal nerve outgrowth was observed in animals that were treated systemically with $5 \mathrm{mg} / \mathrm{kg} /$ day of FK 506 (3); however, experimental studies in animals and clinical observations have shown that FK 506 is potently nephrotoxic, neurotoxic and hyperglycemic in a comparative dose range (4-6). Doses in the range of 0.4 to $1.0 \mathrm{mg} / \mathrm{kg} /$ day showed that the percentage of the glomerular filtrate that was reabsorbed in the proximal tubule increased significantly during FK 506 treatment compared with that in controls (7).

In the present study, we sought to determine whether the local effect of FK 506 has any beneficial effect on functional recovery after sciatic nerve repair.

\section{Animal model}

The study consisted of 18 male Sprague Dawley rats. All rats were housed at the animal care facility at the University of Texas Health Science Center, San Antonio, Texas, and were treated according to the guidelines of the National Society for Medical Research and National Institutes of Health. The 18 rats were randomly assigned to one of three groups, each consisting of six rats. The rats in group $1(n=6)$ underwent sciatic nerve transection and repair, but received no treatment. Similarly, the rats in group $2(n=6)$ underwent surgical repair, but they also received fibrin sealant (FS) locally. Those in group $3(n=6)$ received FK 506 mixed with $\mathrm{FS}$ at the site of nerve repair after the transection.

\section{Pharmacological agents}

FK 506, also known as tacrolimus, is a macrolide immunosuppressant that is produced by Streptomyces tsukubaensis (8). A sterile solution of $1 \mathrm{~mL}$ (equivalent to $5 \mathrm{mg}$ of anhydrous tacrolimus) was mixed with an equal amount of FS solution to deliver $1 \mathrm{mg}$ of FK 506 at the local site.

FS is comprised of cross-linked fibrin units that are polymers of modified fibrinogen monomers. In the past, FS has been an effective matrix for the delivery of antibiotics and chemotherapeutic drugs at a precise local site (9).

\section{Surgical procedure}

Each rat was anesthetized with a mixture of ketamine $(60 \mathrm{mg} / \mathrm{kg})$ and xylazine $(7.5 \mathrm{mg} / \mathrm{kg})$. The initial induction was done by the inhalation of methoxyflurane $(0.5 \%)$. The left gluteal muscle was identified in each rat through a dorsal approach and the muscle was split to expose the sciatic nerve. Approximately $1 \mathrm{~cm}$ above the trifurcation, the nerve was sharply transected with a Bard Parker handle with a number 11 blade (Becton, Dickinson and Company, USA). The cut ends of the nerve were then repaired with 10-0 nylon microepineurial sutures (Ethicon, Inc, USA). The rats in group 1 (control 1) did not receive any treatment, while those in group 2 (control 2) received plain FS around the repair site and those in group 3 (experimental group) received the mixture of FS and FK 506 at the repair site. The overlying muscle and skin were then reapproximated with 3-0 Vicryl sutures (Johnson \& Johnson, USA) and 4-0 Prolene sutures (Ethicon, Inc, USA). 


\section{Assessment of regeneration}

Postoperatively, the animals were examined blindly by an independent observer to assess the functional recovery of the sciatic nerve. The initial signs of the return of toe movement and the ability to walk on toes were noted as weeks to onset. Serial print length factors (PLFs) were then calculated to assess progress, starting in the second week. Walking tracks were obtained by using a narrow wooden corridor in which the rats walked (Figure 1). The hind feet were dipped in tempera paint and the animals walked in the wooden corridor on a plain sheet of paper. The determinations such as footprints and PLF were made once before the surgery and then weekly, beginning in the second week. The recorded footprints were coded and later measured using calipers and a ruler. The normal, contralateral footprint (normal print length [NPL]) was recorded to represent the control footprint and it was compared with that of the experimental footprint (experimental print length [EPL]). The PLF was then determined by the following formula (10):

$$
\mathrm{PLF}=(\mathrm{EPL}-\mathrm{NPL}) / \mathrm{NPL}
$$

The PLF for each group of rats was determined by averaging the individual PLFs of each animal in the group and then comparing groups for statistical significance (Table 1).

\section{Statistical analysis}

The data between the three groups was analyzed by the Kruskal-Wallis test (ie, nonparametric analysis of variance). Where applicable, posthoc analysis for intergroup comparison at different time periods was performed by nonparamet-

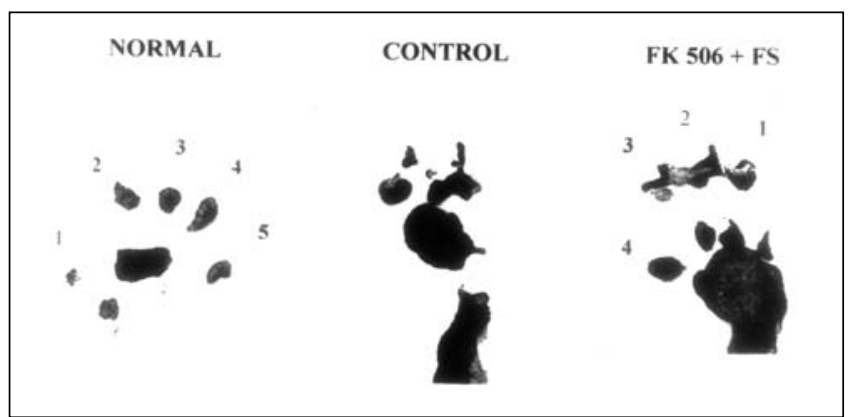

Figure 1) Photographs of footprints from an age-matched normal rat, a rat from the control group (group 1), and a rat from the FK 506 and fibrin sealant-treated group (group 3). Photographs were taken once every week, beginning in the second week. The numbers indicate the toe numbers. A footprint from a normal foot has well spread out and clearly visible toes, whereas the footprint of the rat from the control group shows a dragging effect. The footprint from the rat in group 3 shows a far better picture than the control rat, which indicates good recovery at the same time period

ric Dunn's test. Descriptive statistics were represented as the median and interquartile range. $\mathrm{P}<0.05$ was considered significant for hypothesis testing. The data were analyzed using Minitab statistical software, Version 10 (Minitab Inc, USA) for Microsoft Windows (Microsoft Corporation, USA).

\section{RESULTS}

All 18 rats remained healthy and gained weight for the entire study period. The median time to onset (weeks) of toe movements in the three groups were 4.3 (interquartile

\section{TABLE 1}

\section{Results of nonparametric analysis for print length factor in three groups at different time periods}

Print length factor: median (interquartile range)

\begin{tabular}{|c|c|c|c|c|c|c|c|}
\hline Time period & $\begin{array}{l}\text { Group } 1 \\
\text { (control) }\end{array}$ & $\begin{array}{c}\text { Group } 2 \\
\text { (fibrin glue) }\end{array}$ & $\begin{array}{c}\text { Group } 3 \\
\text { (fibrin glue and FK 506) }\end{array}$ & $\mathbf{P}$ & $\begin{array}{l}\text { Group } 1 \\
\text { versus } \\
\text { group } 2\end{array}$ & $\begin{array}{l}\text { Group } 1 \\
\text { versus } \\
\text { group } 3\end{array}$ & $\begin{array}{c}\text { Group } 2 \\
\text { versus } \\
\text { group } 3\end{array}$ \\
\hline Week 2 & $0.75(0.71-0.79)$ & $0.75(0.74-0.79)$ & $0.81(0.78-0.82)$ & NS & NA & NA & NA \\
\hline Week 3 & $0.69(0.68-0.72)$ & $0.72(0.69-0.74)$ & $0.79(0.74-0.80)$ & 0.026 & NS & $P<0.05$ & NS \\
\hline Week 4 & $0.66(0.64-0.71)$ & $0.70(0.69-0.72)$ & $0.71(0.70-0.76)$ & NS & NA & NA & NA \\
\hline Week 5 & $0.59(0.57-0.61)$ & $0.66(0.64-0.69)$ & $0.52(0.49-0.55)$ & 0.001 & NS & NS & $P<0.05$ \\
\hline Week 6 & $0.57(0.54-0.60)$ & $0.62(0.61-0.64)$ & $0.41(0.38-0.51)$ & 0.001 & NS & NS & $P<0.05$ \\
\hline Week 7 & $0.50(0.48-0.53)$ & $0.46(0.44-0.53)$ & $0.35(0.30-0.42)$ & 0.04 & NS & $P<0.05$ & NS \\
\hline Week 8 & $0.44(0.40-0.49)$ & $0.38(0.35-0.45)$ & $0.31(0.30-0.37)$ & 0.029 & NS & $P<0.05$ & NS \\
\hline Week 9 & $0.37(0.34-0.41)$ & $0.32(0.31-0.40)$ & $0.27(0.23-0.34)$ & 0.029 & NS & $P<0.05$ & NS \\
\hline Week 10 & $0.33(0.29-0.35)$ & $0.30(0.29-0.40)$ & $0.25(0.23-0.32)$ & 0.003 & NS & $P<0.05$ & $P<0.05$ \\
\hline
\end{tabular}
intergroup comparison Group 1 Group 1 Group

Posthoc analysis for 


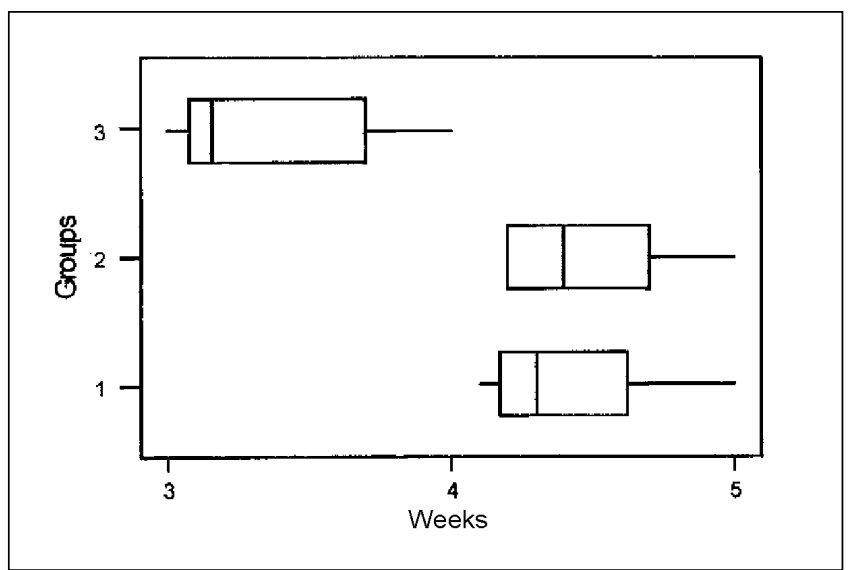

Figure 2) Bar plot of functional recovery following sciatic nerve repair in three groups of rats ( $n=6$ in each group). Local delivery of $1 \mathrm{mg}$ of FK 506, mixed in fibrin sealant, enhances the axonal regeneration. The above plot shows seven to eight days of earlier recovery in group 3 (the experimental group) compared with that in groups 1 and 2 (control groups)

range [IQR] 4.17 to 4.63 ) for group 1, 4.4 (IQR 4.20 to 4.70) for group 2 and 3.15 (IQR 3.07 to 3.70 ) for group 3 (Figure 2). The difference was statistically significant between the experimental rats (group 3) and the control rats (groups 1 and 2) $(\mathrm{P}<0.003)$. Further, posthoc analysis revealed significant differences $(\mathrm{P}<0.05)$ between the groups. In other words, the initial return of motor function that was observed as toe movement and the ability to walk on toes were noted approximately one week (seven to eight days) earlier in group 3 (rats that received FK 506 and FS) than in the other two groups. There was no difference between groups 1 and 2 .

Figure 3 shows the mean PLFs in the three groups at oneweek time intervals. Although the PLFs improved gradually in all three groups, there was an earlier significant improvement in group 3 than in the other groups. For example, mean PLFs of the rats in group 3 showed sudden improvement between four and five weeks, whereas the improvements in groups 1 and 2 started toward normalization one week later, between five and six weeks. There was, however, no significant difference between groups 1 and 2 . Further, the mean PLF of each group fell short of reaching the preoperative level of zero as a result of the short study period of 11 weeks.

\section{DISCUSSION}

Although the precise incidence of peripheral nerve injury is unknown, it is one of the most common traumatic upper extremity injuries. Studies of war victims (soldiers and civilians alike) have shown that peripheral nerve injuries account for approximately $70 \%$ to $80 \%$ of all trauma $(11,12)$. In the past decade, the focus of neurobiological research has been to develop an ideal nerve growth factor that enhances axonal growth in terms of the rate of advancement and the density of nerve fibres. A variety of agents, such as nerve growth factor (13), laminin (14),

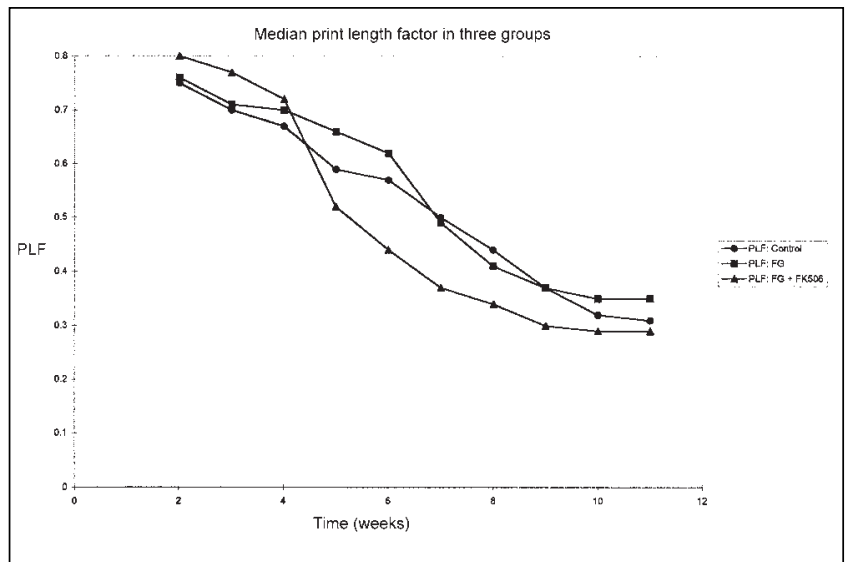

Figure 3) Print length factors (PLFs) during recovery after sciatic nerve repair by end-to-end coaptation. The sudden drop toward normalization of PLF (normal $=$ a preoperative level of zero) in group 3 around the fourth week after surgery indicates an earlier recovery pattern. The preoperative level was not reached in any of the groups because the duration of the study period was cut short in the 11th week. FG Fibrin glue

adrenocorticotrophin (15), cyclosporin A (16) and, recently, FK 506, have been examined experimentally. Investigations in rats have determined that both FK 506 and its analogues increase the rate of axonal advancement and nerve fibre count compared with controls (17-19); however, experimental studies in animals, as well as clinical observations, have shown that FK 506 is potently nephrotoxic, neurotoxic and hyperglycemic in a comparative dose range ( 0.4 to $1.0 \mathrm{mg} / \mathrm{kg} /$ day) (4-6). For example, rats that were treated with $0.8 \mathrm{mg} / \mathrm{kg} /$ day of FK 506 showed a $23 \%$ decrease in glomerular filtration rate at four weeks compared with that in controls (20). Similarly, acute nephrotoxicity, in the form of increased blood urea nitrogen and plasma creatinine levels, was demonstrated in hypertensive rats when they were injected with $1 \mathrm{mg} / \mathrm{kg} /$ day of FK 506 for two weeks (21). Therefore, to avoid the systemic side effects of the drug, the present study tested the regenerative potential of FK 506 delivered locally in a rat sciatic model.

In the present study, comparisons were made among three groups of rats, one of which was treated with $1 \mathrm{mg}$ of FK 506 delivered locally after nerve transection and primary repair (group 3). The second group (group 2) received FS and group 1 received only normal saline. Both groups 1 and 2 were used as controls. In addition to acting as a slow drug delivery vehicle, FS could potentially seal the neuroraphy site. Functional recovery among the three groups was assessed by a walking track analysis. Overall, the animals that received FK 506 showed earlier recovery than those in the control groups. The experimental group that showed one week (seven to eight days) of earlier onset of toe movement and the ability to walk indicates increased axon counts and augmentation in the rate of axonal elongation. In vivo studies of sciatic nerve models have demonstrated this effect (1). FK 506 has also been shown to promote neurite outgrowth in cultures of rat dorsal root ganglia (22). Intergroup analysis comparing the mean PLFs during each 
week (starting at two weeks) demonstrated a significant earlier recovery spurt between four and five weeks in the FK 506-treated animals compared with those in the other two groups. In the later part of the study, similar significance was noted in group 3 compared with group 1, rather than with group 2 . The small sample size could be the reason for this difference.

The exact mechanism by which FK 506 enhances nerve regeneration is not known. One of the possible pathways that has been suggested is through the binding of FK 506 to FK 506-binding protein 12, which, in turn, enhances phosphorylation of growth associated protein 43 . Further, it has been noted that the activation of growth-associated protein 43 aids in the elongation of axons and nerve fibres (23). An alternate mechanism that has been suggested is the association between FK 506-binding protein 12 and calcium release channels such as the inositol 1,4,5-triphosphate receptor and the ryanodine receptor. The inhibition of inositol 1,4,5-triphosphate and the activation of type I transforming growth factor beta receptors have also been noted to enhance axonal growth (24).

Local delivery of FK 506 at the site of nerve repair requires absorption at the site. Internalization by endocyto- sis and retrograde axonal transport of neurotrophins are known to occur at the nerve terminal (25). It is tempting to speculate that the same mechanism could also be applied to the absorption and transport of FK 506.

\section{SUMMARY}

This study demonstrates good functional recovery in rats that were locally treated with FK 506 at the site of sciatic nerve repair. Local delivery of the drug potentially eliminates its systemic side effects. Further, in vivo studies in which FK 506 is impregnated into a nerve conduit are presently underway in our laboratory at the University of Texas Health Science Center. The long term goal of our experiment is to develop an off-the-shelf FK 506 nerve conduit to be used during nerve repairs, which will significantly improve the recovery time of a peripheral nerve injury.

ACKNOWLEDGEMENTS: This study was funded fully by San Antonio Area Foundation, Texas. We appreciate their generous contribution to the field of peripheral nerve regeneration. We thank Dr Mantha Srinivas for his editorial comments and statistical analysis. We also appreciate the helpful hand of Dr Alexandro Jaramillo.

\section{REFERENCES}

1. Gold BG, Storm-Dickerson T, Austin DR. The immunosuppressant FK 506 increases functional recovery and nerve regeneration following peripheral nerve injury. Restor Neurol Neurosci 1994;6:287-96.

2. Gold BG, Katoh K, Storm-Dickerson T. The immunosuppressant FK506 increases the rate of axonal regeneration in rat sciatic nerve. J Neurosci 1995;15:7509-16.

3. Wang MS, Zeleny-Pooley M, Gold BG. Comparative dose dependence study of FK 506 and Cyclosporin A on the rate of axonal regeneration in the rat sciatic nerve. J Pharmacol Exp Ther 1997;282:1084-97.

4. Kumano K, Wang G, Endo T, Kuwao S. FK 506-induced nephrotoxicity in rats. Transplant Proc 1991;23:512-5.

5. McCauley J. The nephrotoxicity of FK 506 as compared with cyclosporin. Curr Opin Nephrol Hypertens 1993;2:662-9.

6. Mizisin AP, Powell HC. Toxic neuropathies. Curr Opin Neurol 1995;8:367-71.

7. Nielsen FT, Leyssac PP, Kemp E, Starklint H, Dieperink H. Nephrotoxicity of FK 506: A preliminary study on comparative aspects of FK 506 and cyclosporin nephrotoxicity. Transplant Proc 1994;26:3104-5.

8. Kino T, Hatanaka H, Hashimoto M, et al. FK 506, a novel immunosuppressant isolated from Streptomyces. I. Fermentation, isolation, and physico-chemical and biological characteristics. J Antibiot 1987;40:1249-55.

9. Deyerling W, Haverich A, Potel J, Hetzer R. A suspension of fibrin glue and antibiotic for local treatment of mycotic aneurysms in endocarditis - an experimental study. Thorac Cardiovasc Surg 1984;32:369-72.

10. Hare GM, Evans PJ, Mackinnon SE, et al. Walking track analysis: A long-term assessment of peripheral nerve recovery. Plast Reconstr Surg 1992;89:251-8.

11. Vrebaov-Cindro V, Reic P, Ognjenovic M, et al. Peripheral nerve war injuries. Mil Med 1999;164:351-2.

12. Dillingham TR, Spellman NT, Braverman SE, et al. Analysis of casualities referred to army physical medicine services during the Persian Gulf conflict. Am J Phys Med Rehabil 1993;72:214-8.

13. Gundersen RW, Barrett JN. Characterization of the turning response of dorsal root neurites toward nerve growth factor. J Cell Biol 1980;87:546-54.

14. Strand FL, Kung TT. ACTH accelerates recovery of neuromuscular function following crushing of peripheral nerve. Peptides 1980;1:135-8.

15. Gundersen RW. Response of sensory neurites and growth cones to patterned substrata of laminin and fibronectin in vitro. Dev Biol 1987;121:423-31.

16. Liu J, Farmer JD Jr, Lane WS, Friedman J, Weissman I, Schreiber SL. Calcineurin is a common target of cyclophilincyclosporin A and FKBP-FK 506 complexes. Cell 1991;66:807-15.

17. Steiner JP, Connolly MA, Valentine HL, et al. Neurotrophic actions of immunosuppressive analogues drugs FK 506, rapamycin and cyclosporin A. Nat Med 1997;3:421-8.

18. Fansa H, Keilhoff G, Altmann S, Plogmeier K, Wolf G, Schneider W. The effect of the immunosuppressant FK 506 on peripheral nerve regeneration following nerve grafting. J Hand Surg [BR] 1999;24:38-42.

19. Doolabh VB, Mackinnon SE. FK 506 accelerates functional recovery following nerve grafting in a rat model. Plast Reconstr Surg 1999;103:1928-36.

20. Nielsen FT, Leyssac PP, Kemp E, Starklint H, Dieperink H. Nephrotoxicity of FK-506 in the rat. Studies on glomerular and tubular function, and on the relationship between efficacy and toxicity. Nephrol Dial Transplant 1995;10:334-40.

21. Mitamura T, Yamada A, Ishida H, et al. Tacrolimus (FK 506)induced nephrotoxicity in spontaneous hypertensive rats. J Toxicol Sci 1994;19:219-26.

22. Lyons WE, George EB, Dawson TM, Steiner JP, Snyder SH. Immunosuppressant FK 506 Promotes Neurite Outgrowth in Cultures of PC12 Cells and Sensory Ganglia. Proc Natl Acad Sci, USA 1994;91:3191-5.

23. Lyons WE, Steiner JP, Snyder SH, Dawson TM. Neuronal regeneration enhances the expression of the immunophilin FKBP-12. J Neurosci 1995;15:2985-94.

24. Brillantes AB, Ondrias K, Scott A, et al. Stabilization of calcium release channel (ryanodine receptor) function by FK 506-binding protein. Cell 1994;77:513-23.

25. Weible M 2nd, Bartlett S, Reynolds AJ, Hendry IA. Prolonged recycling of internalized neurotrophins in the nerve terminal. Cytometry 2001:43;182-8. 